Invertebrate Reproduction \& Development

\title{
Population biology and size at the onset of sexual maturity of the amphidromous prawn Macrobrachium olfersii (Decapoda, Palaemonidae) in an urban river in southeastern Brazil
}

Régis Augusto Pescinelli, Mariana Fronja Carosia, João Alberto Farinelli Pantaleão, Sabrina Morilhas Simões \& Rogerio Caetano Costa

To cite this article: Régis Augusto Pescinelli, Mariana Fronja Carosia, João Alberto Farinelli Pantaleão, Sabrina Morilhas Simões \& Rogerio Caetano Costa (2016) Population biology and size at the onset of sexual maturity of the amphidromous prawn Macrobrachium olfersii (Decapoda, Palaemonidae) in an urban river in southeastern Brazil, Invertebrate Reproduction \& Development, 60:4, 254-262, DOI: 10.1080/07924259.2016.1202338

To link to this article: https://doi.org/10.1080/07924259.2016.1202338

册 Published online: 27 Jun 2016.

Submit your article to this journal $₫$

Џll Article views: 147

View Crossmark data \lceil

Citing articles: 3 View citing articles $\square$ 


\title{
Population biology and size at the onset of sexual maturity of the amphidromous prawn Macrobrachium olfersii (Decapoda, Palaemonidae) in an urban river in southeastern Brazil
}

\author{
Régis Augusto Pescinellia ${ }^{a}$ Mariana Fronja Carosia ${ }^{b}$, João Alberto Farinelli Pantaleãoa, Sabrina Morilhas Simões ${ }^{a}$ \\ and Rogerio Caetano Costa ${ }^{a}$
}

aLaboratory of Biology of Marine and Freshwater Shrimp (LABCAM), Faculdade de Ciências, Departamento de Ciências Biológicas, UNESP, Bauru, Brazil; 'bepartment of Hydraulics and Sanitation, University of São Paulo (USP), Campus São Carlos, São Carlos, Brazil

\begin{abstract}
Information on population biology is essential for a better understanding of the ecological stability of a species and the ecosystem in which it lives, especially in areas affected by anthropogenic activities. This study investigated the population biology of Macrobrachium olfersii in an ecosystem under human impact, focusing on sex ratio, reproductive period, and juvenile recruitment. The onset of sexual maturity was also estimated. Samplings were performed monthly in the daytime from June 2006 to May 2007 on the Taquaral River in the city of Ubatuba, São Paulo State, Brazil. The sex ratio was skewed towards females, and both the reproductive period and the juvenile recruitment were continuous. The estimated size at which the species reached sexual maturity corroborated studies on populations from other locations. Results from the current study strongly indicate that the ecosystem studied may have suffered environmental stress, which probably interfered with the migration and establishment of the species: during the study, the species was found in significant abundance, but six years later, it was not captured in samplings.
\end{abstract}

\section{ARTICLE HISTORY}

Received 7 May 2016

Accepted 10 June 2016

\section{KEYWORDS}

Freshwater prawn; reproduction; tropical river; sex ratio; Caridea

\section{Introduction}

Caridean shrimp inhabit marine and freshwater environments; some caridean shrimp are exclusively marine or exclusively freshwater species (Bauer 2004; Bauer \& Delahoussaye 2008). Some freshwater species, such as some atyids and palaemonids, need saltwater or the brackish water of estuaries to complete their larval development (Bauer 2004).

Species that migrate between fresh water and marine environments for reproductive purposes are referred to as amphidromous (Bauer 2004). Among the Palaemonidae, amphidromy occurs most commonly in the genus Macrobrachium Spence Bate, 1868. In species of this genus, some females live and can spawn in fresh water; however, females of some species may migrate downstream before spawning (Bauer 2004). Even larvae hatched in fresh water are transported during high flows to the estuary and will develop and migrate to a freshwater environment after reaching the decapodite or juvenile stage (Ammar et al. 2001; Mossolin \& Bueno 2002; Bauer 2004).

The freshwater prawn Macrobrachium olfersii (Wiegmann, 1836) is an amphidromous representative of the Americas that is distributed from the east coast of the United States to southern Brazil (Holthuis \& Provenzano 1970). Some authors have suggested the occurrence of more than one species along this wide geographical distribution; however, molecular studies have shown it to be a single species (Rossi \& Mantelatto 2013). Macrobrachium olfersii inhabits the marginal vegetation of rivers and streams that flow directly to the sea (Holthuis \& Provenzano 1970) and requires high salinity values for larval development (Dugger \& Dobkin 1975).

Information on the population biology of a species, such as sex ratio, reproductive period, juvenile recruitment and the size at which individuals reach sexual maturity, are essential for understanding the species' life history. In addition to environmental factors such as temperature, photoperiod and the availability and quality of food (Campbell \& Robinson 1983), human activities also influence population dynamics. Human activities may change these parameters and therefore interfere with establishment of the species in the environment (Simons \& Jones 1981). Urbanisation influences a range of factors involved in stream health, including the hydrologic regime, water quality and riparian conditions. In this way, urbanisation

CONTACT Rogerio Caetano Costa rccosta@fc.unesp.br 


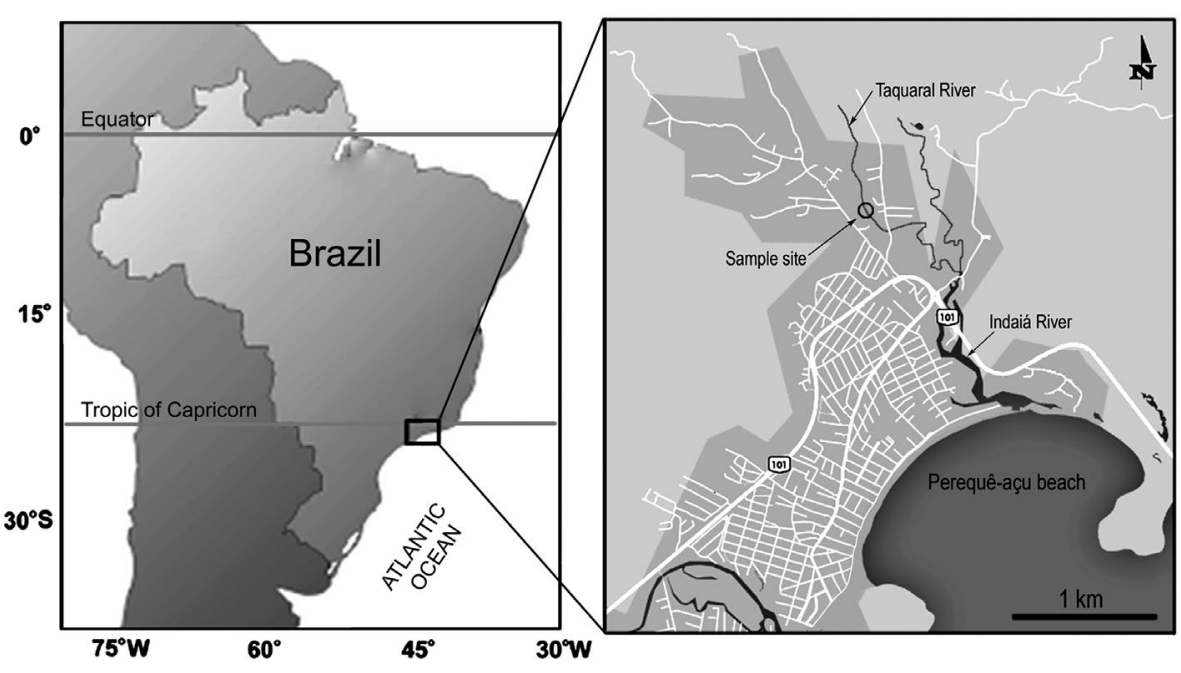

Figure 1. Map of sampling site in the urban area of Ubatuba, São Paulo, South-eastern Brazil. Streets and roads are represented by white lines.

has negative effects on terrestrial and aquatic ecosystems (Pérez-Reyes et al. 2016).

The life cycle of amphidromous shrimp (and particularly migration) may change or even be interrupted by human impacts on lotic habitats (Bauer 2011). Dam construction (Holmquist et al. 1998), pollution (Cooney \& Kwak 2013), and water abstraction and/or river deviation (March et al. 2003) are among the most destructive human activities for river ecosystems. These influences lead to habitat loss, degradation and fragmentation (Cooney \& Kwak 2013). Considering this scenario, the aim of this study was to evaluate the population biology of $M$. olfersii in an environment influenced by human impact by focusing on the reproductive period and sex ratio and also by estimating the onset of sexual maturity. We also verified the relationship of water temperature and rainfall with abundance of ovigerous females and juveniles of $M$. olfersii.

\section{Materials and methods}

\section{Study area}

Sampling was performed on the Taquaral River $\left(23^{\circ} 40^{\prime} 42.9^{\prime \prime}\right.$ $S 45^{\circ} 06^{\prime} 38.9^{\prime \prime} \mathrm{W}$ ) (Figure 1), a tributary of the Indaiá River in the urban area of around the city of Ubatuba, located on the northern coast of São Paulo State in Brazil. The basin formed by the Indaiá River and the Capim Melado stream is the second largest in human occupation and the third largest in deforested area of the municipality (data sourced from https://cuidagua.com). The mouth of the Indaiá River has high contamination rates from pesticides and chemical fertilisers used in farming areas near the river. Additional impacts include domestic sewage dumped by the local population, the accumulation of garbage on the river banks, and there is bottom sand extraction (data sourced from https://www.sosma.org.br).

The sampling area was located approximately $1.5 \mathrm{~km}$ from the sea and $2 \mathrm{~km}$ from the coastal mountain range known as the Serra do Mar. Sampling was performed in a lotic environment on the Taquaral River. This river is approximately $11 \mathrm{~m}$ wide and an average of $75 \mathrm{~cm}$ deep. It has clear waters and its sediment is composed predominantly of sand, gravel and stones. The vegetation on the banks is composed of grasses and aquatic macrophytes.

\section{Sampling and data analysis}

Sampling was performed monthly in the daytime from June 2006 to May 2007. Prawns were collected in the vegetation along the edge of the river using a rectangular gillnet with an area of $80 \times 50 \mathrm{~cm}$ and a mesh size of $5 \mathrm{~mm}$. Two researchers performed the sampling for a 30-min period, which corresponded to sweeps on the banks of approximately 100 linear metres.

Water temperatures were monitored monthly with a mercury thermometer. Monthly rainfall was obtained from the Brazilian Integrated Agricultural Weather Data Center (http://www.ciiagro.sp.gov.br). Prawns were placed in labelled plastic bags, transported to the laboratory, and kept frozen until analysis.

All individuals captured were identified according to Melo (2003). Carapace length (CL), defined as the posterior margin of the ocular orbit to the posterior margin of the carapace, and total length ( $T L$ ), defined as the posterior margin of the ocular orbit to the posterior margin of the telson were measured with a digital caliper $(0.01 \mathrm{~mm})$. Individuals were sexed according to the presence (males) or absence (females) of the male appendage in the endopod of the 
Table 1. Macrobrachium olfersii. Body size of each demographic category of the population of Ubatuba, São Paulo state, from June 2006 to May 2007.

\begin{tabular}{|c|c|c|c|c|}
\hline Demographic category & $N$ & $\operatorname{Min}-\operatorname{Max}(C L-m m)$ & Mean \pm SD & $\%$ \\
\hline Undifferentiated juveniles & 24 & $2.5-3.0$ & $2.8 \pm 3.9$ & 1.9 \\
\hline Juvenile males & 219 & $3.1-6.4$ & $4.4 \pm 3.8$ & 16.9 \\
\hline Adult males & 197 & $6.9-21.4$ & $11.82 \pm 3.8$ & 15.2 \\
\hline Juvenile females & 590 & $3.1-6.6$ & $4.2 \pm 3.7$ & 45.7 \\
\hline Females without eggs & 131 & $6.7-17.9$ & $9.27 \pm 3.8$ & 10.2 \\
\hline Females with eggs & 130 & $7.9-21.5$ & $12.3 \pm 3.9$ & 10.1 \\
\hline Total & 1291 & $2.5-21.5$ & $6.9 \pm 3.8$ & 100 \\
\hline
\end{tabular}

Note: $\mathrm{SD}=$ standard deviation.

second pair of pleopods (Valenti 1998). Individuals smaller than the smallest male found in the study period were considered to be undifferentiated juveniles. Male specimens were classified according to a methodology adapted from Bauer (1989) in which juvenile individuals are defined as smaller specimens corresponding to $25 \%$ of all size classes observed (also understood as the first classes). Females in size classes smaller than the estimated value for the onset of sexual maturity were considered to be juveniles.

Normality was checked using the Shapiro-Wilk test (Zar 1996). CL (mm) for each sex was compared separately for juveniles and adults using the Mann-Whitney test $(\alpha=0.05)$ (Zar 1996). A chi-square test $(x 2)$ with a significance level of $5 \%$ was applied to determine whether sex ratio was steady at 0.50 (a 1:1 ratio) or varied between months (Sokal \& Rohlf 1995). No test was used in months and size classes in which fewer than 20 specimens were collected or when one sex was not captured (Vieira, 2011).

Gonadal maturation stages were set for females based on variations in the size and colour of the ovaries (Mossolin \& Bueno 2002), as follows: stage I - translucent ovaries extending anteriorly to half of the hepatopancreas length; stages II and III - whitish or light green-coloured ovaries extending to or slightly beyond the hepatopancreas edge; stage IV - ovaries with olive green colouring, extending anteriorly to the last rostrum spine; and stage $\mathrm{V}$ - fully developed dark green ovaries reaching the penultimate dorsal rostrum spine.

The reproductive period was determined by the monthly number of ovigerous females and reproductive females (ovarian stages IV-V). Juvenile Recruitment was defined as the number of undifferentiated juveniles plus the number of immature males and females in each month and season.

Cross-correlation (StatSoft 2001) was applied (Sokal \& Rohlf 1981) to evaluate the correlation between environmental factors (water temperature and rainfall) and the abundance of ovigerous females and juveniles.

The L50 method was used to estimate the onset of sexual maturity. This method distributes (\%) specimens into size classes using $\mathrm{CL}$ as an independent variable and the relative frequencies as a dependent variable. The data were then fitted to a sigmoid curve following the results of the logistic equation $\left(y=1 /\left(1+e^{r(C L-C L 50)}\right)\right)$, where $C L 50$ is the $C L$ at which $50 \%$ of individuals reach maturity and $r$ is the slope. The adjustment equation was performed using the method of least squares (Vazzoler 1996), by estimating the value of maturity (CL50), and using interpolation (50\%).

\section{Results}

During the study period, 1291 prawns were collected. Of these, 24 specimens were undifferentiated juveniles, 219 were juvenile males, 197 were adult males, 590 were juvenile females, 131 were non-ovigerous females, and 130 were ovigerous females. Water temperature ranged from $18^{\circ} \mathrm{C}$ to $26^{\circ} \mathrm{C}$, and rainfall ranged from $31.6 \mathrm{~mm}$ to $326.6 \mathrm{~mm}$. The size ranges recorded for each demographic class are shown in Table 1. There was no statistically significant difference between the mean size of males and females in any of the demographic categories (juveniles and adults) (Mann-Whitney; $p>0.05$ ).

Based on the data from the entire study period, the sex ratio was 2.05:1 ( $\left(: 0^{\prime}\right)$. With the exception of December 2006 , there was a predominance of females in relation to males in every month (Table 2).

Females with developing and developed gonads (IV-V) occurred in almost all months, with the exception of March 2007 (Figure 2). Ovigerous females also occurred in almost all months except March 2007, with peaks in November 2006 and January and February 2007 (Figure 3). There was no statistically significant correlation between the abundance of ovigerous females and temperature or rainfall (cross-correlation $p>0.05$ ).

A total of 839 juveniles were collected. The highest abundance occurred from June to October 2006, during which period the lowest temperature and rainfall values were also recorded (Figure 3 ). The cross-correlation analysis revealed a negative correlation $(p<0.05$ and $r=0.70)$ between temperature and the number of juveniles, indicating a time lag of zero months between the number of juveniles and the monthly water temperature (Figure 4).

Adjustment of the logistic equation indicated the $\mathrm{CL}$ at which $50 \%$ of females were mature as $6.70 \mathrm{~mm}$ (Figure 5) 
Table 2. Macrobrachium olfersii. Proportion of male and female. The deviation from an equal sex ratio was tested for each month.

\begin{tabular}{|c|c|c|c|c|c|}
\hline Month & Males & Females & $p$ & $x^{2}$ & Q: $0^{\prime \prime}$ \\
\hline Jun/06 & 30 & 96 & $<0.05$ & 34.57 & $3.20: 1$ \\
\hline Jul/06 & 42 & 179 & $<0.05$ & 84.93 & $4.26: 1$ \\
\hline Aug/06 & 40 & 98 & $<0.05$ & 24.38 & $2.45: 1$ \\
\hline Sep/06 & 130 & 152 & $<0.05$ & 1.72 & $1.17: 1$ \\
\hline Oct/06 & 42 & 83 & $<0.05$ & 13.45 & $1.98: 1$ \\
\hline Nov/06 & 53 & 57 & $<0.05$ & 0.14 & $1.08: 1$ \\
\hline Dec/06 & 18 & 17 & $<0.05$ & 0.03 & $0.94: 1$ \\
\hline Jan/07 & 41 & 91 & $<0.05$ & 18.94 & $2.22: 1$ \\
\hline Feb/07 & 16 & 69 & $<0.05$ & 33.05 & 4.31:1 \\
\hline Mar/07 & 3 & 1 & - & - & - \\
\hline Apr/07 & 0 & 3 & - & - & - \\
\hline May/07 & 1 & 5 & - & - & - \\
\hline Total & 416 & 851 & $<0.05$ & 149.35 & $2.05: 1$ \\
\hline
\end{tabular}

Note: The test was not applied in the months when the number of individuals sampled was less than 20.

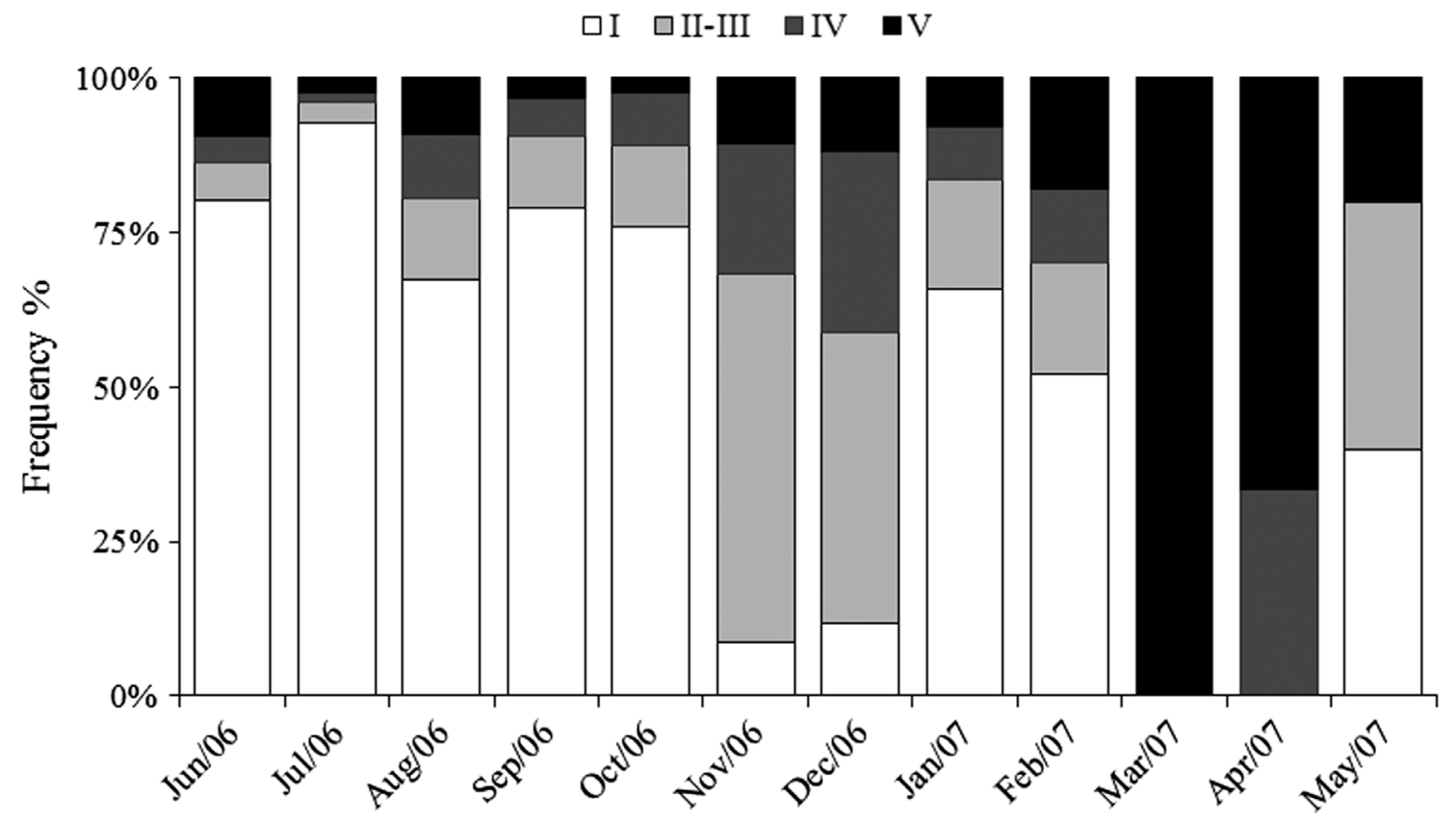

Figure 2. Macrobrachium olfersii. Number of females with different ovarian development stages (I - immature gonads, II and III - rudimentary gonads, IV - developing gonads and V - gonads fully developed).

according to the gonadal development analysis. Analysis of frequency distribution per size class showed the presence of ovigerous females in size classes up to $7 \mathrm{~mm} \mathrm{CL}$, with higher abundance in size classes between 9 and 17 mm CL (Figure 6).

\section{Discussion}

The presence of males which were larger in size than the females is a feature commonly found among the Caridea, and especially among Macrobrachium species. This difference is likely associated with reproductive success and intraspecific competition, since larger males have a higher chance of copulation (Gherardi \& Micheli 1989). No statistically significant difference in mean size was found between male and female $M$. olfersii specimens, even when juveniles and adults were analysed separately. Adult males seemed to be found at larger sizes relative to females, a difference which is likely owing to the second pereopod being more developed. Although both sexes exhibited heterochely in the second pereopod, this characteristic was more evident in males (Mossolin \& Bueno 2003).

The predominance of females in relation to males found in the present study was also observed in other $M$. olfersii populations, such as the 2:1 ratio ( $\%: 0^{\prime \prime}$ ) observed in Santa Catarina State (Barros 1995) and the 4.3:1 ratio (\$:O') in São Sebastião, São Paulo State (Mossolin \& Bueno 2002). The prevalence of females usually occurs in periods of higher reproductive intensity. However, our results showed a sex ratio skewed towards females throughout most of study period, not only in the reproductive period, a finding also reported by Mossolin and Bueno (2002). Possible factors 

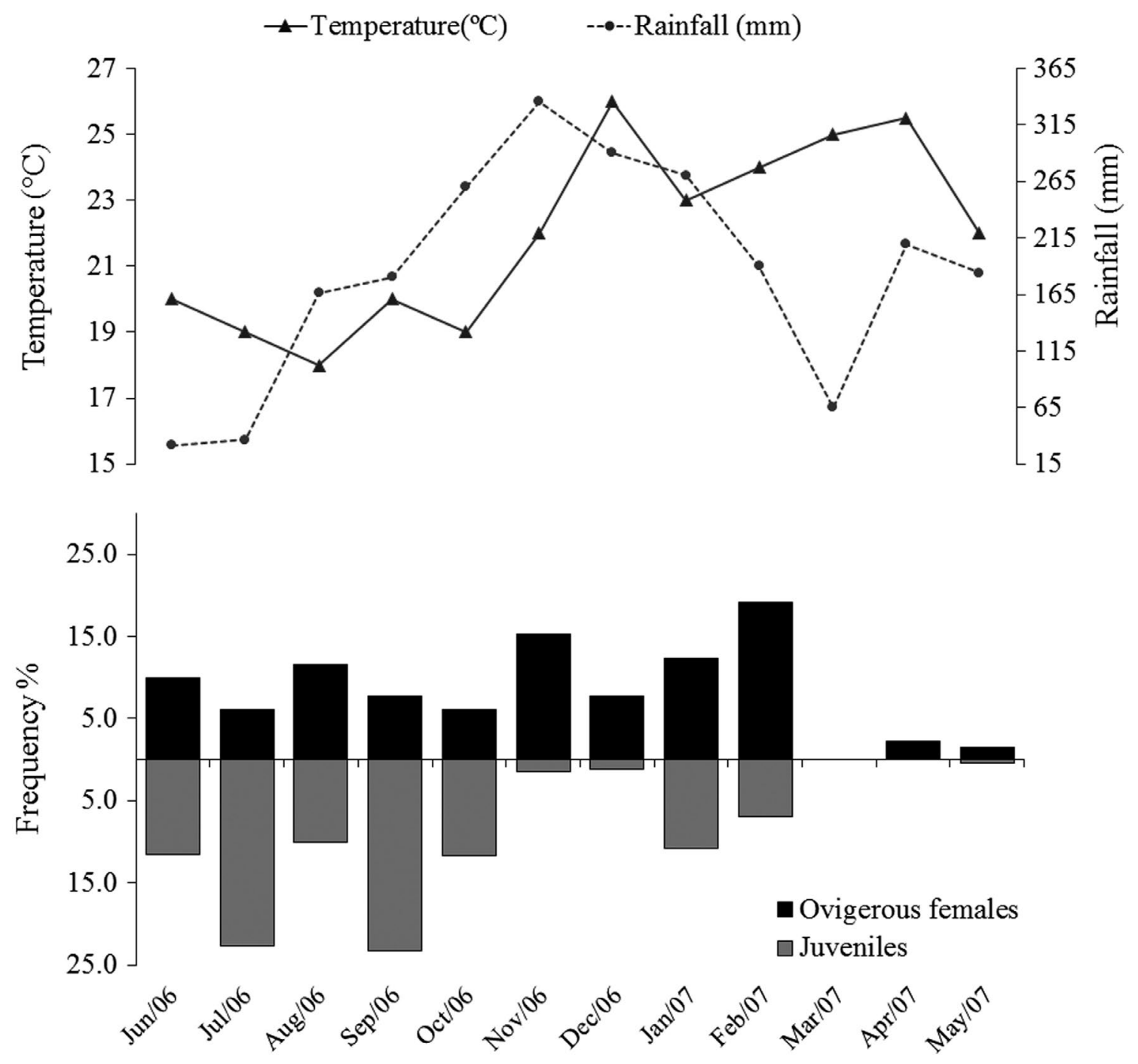

Figure 3. Macrobrachium olfersii. Relationship of monthly temperature and rainfall with the number of ovigerous females and juveniles.

that explain this anomalous pattern found in sex ratio include different growth and mortality rates between sexes, different rates of migration (Wenner 1972), and sex-specific behaviour patterns, all of which can hamper the capture of large adult males using fishing tackle (Valenti 1985). Macrobrachium species inhabit shelters, and adult males' long chelipeds allow them to defend their shelter without leaving it (Valenti 1985; Moraes-Riodades \& Valenti 2004).

The results of the present study (the presence of stages IV and V females with embryos throughout most of the study period) showed that $M$. olfersii exhibits continuous reproduction but with peaks of higher spawning activity between late spring and summer (from November 2006 to February 2007). A population of M. olfersii studied in São Sebastião, São Paulo presented similar results (Mossolin \& Bueno 2002): ovigerous females were sampled in every month of the year, and peaks were found between October and April. There is a tendency among crustaceans to extend the reproductive period or even to exhibit continuous reproduction throughout the year as latitude decreases owing to high temperatures and high productivity (Sastry 1983). Additionally, estuaries in tropical regions have high nutrient levels (Levinton 1995), so species with part of their life cycle in this ecosystem such as $M$. olfersii benefit.

The lack of ovigerous females and their low abundance in March 2007 are probably associated with the climatic variability observed at the study site in that month. Although the monthly rainfall was lower than the period from December 2006 to February 2007, heavy rainfall occurred on the sampling day and increased the river current (Rogerio Caetano da Costa, personal communication). This condition hampered sampling, since the strong current hindered fishing tackle management. The current may have also influenced the population by shifting it to places farther down the river which were not part of the sampling sites. 


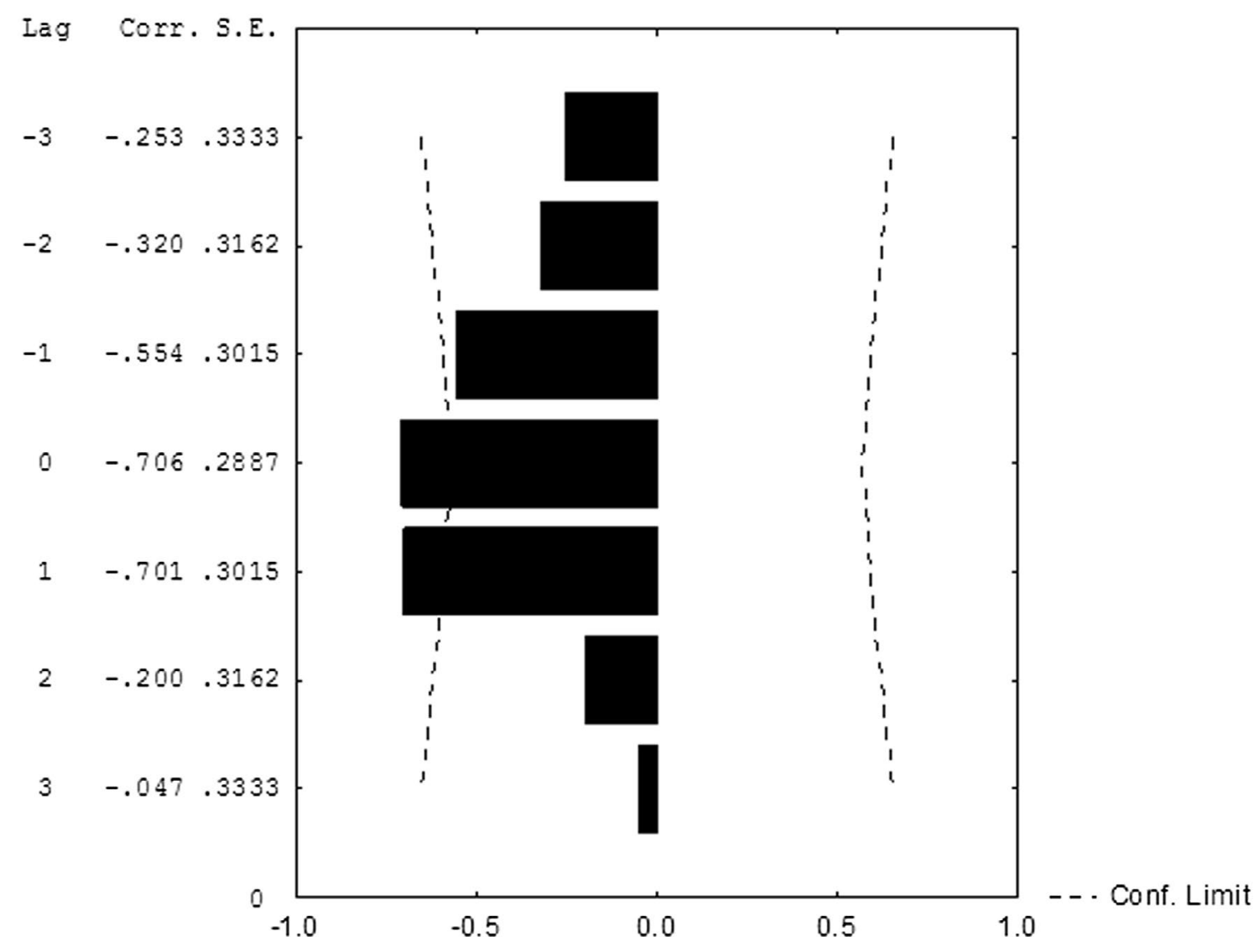

Figure 4. Macrobrachium olfersii. Cross correlation analysis between juvenile frequency and monthly water temperature.

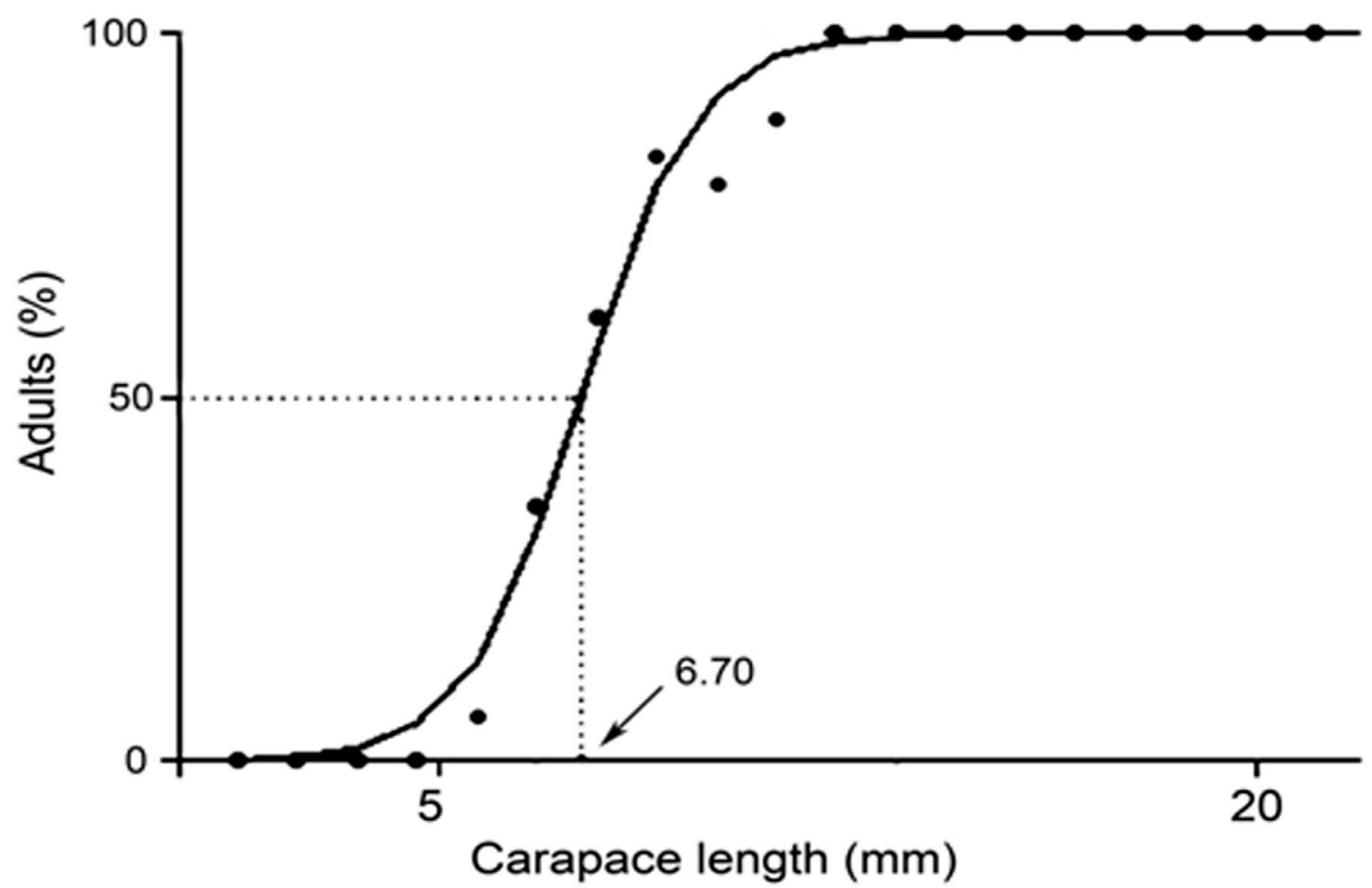

Figure 5. Macrobrachium olfersii. Adjustment of the logistic equation indicating the carapace length at which $50 \%$ of females were mature, according to gonadal development analysis. 


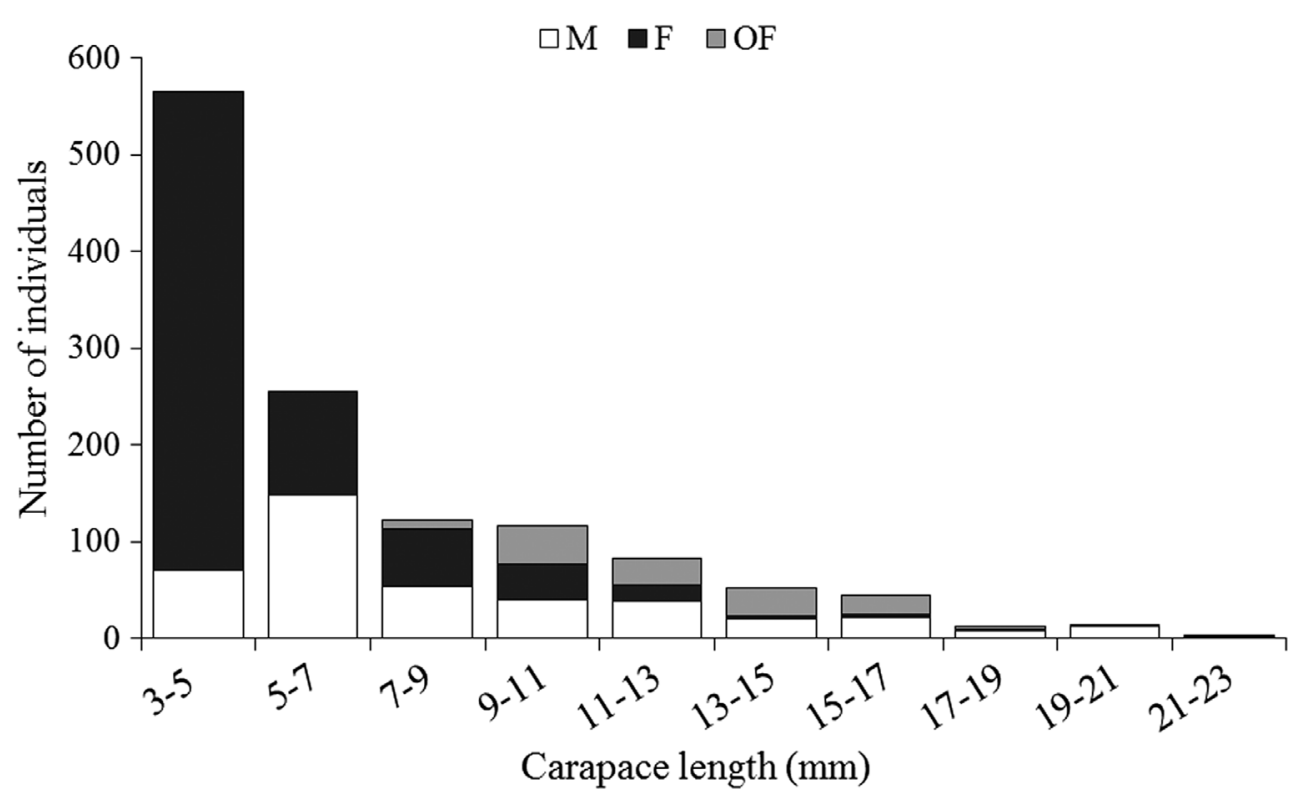

Figure 6. Macrobrachium olfersii. Size-frequency distribution for males ( $M$ - white bars), non-ovigerous females ( $F$ - black bars) and ovigerous females (OF - grey bars).

Because the river sampled is located in an urban area, an increase in its flow may occur as a result of the outflow of street/road waters during periods of rain. Studies on direct connections between rivers and roads found that roads change hydrographic characteristics by increasing surface runoff and sedimentation rates (Trombulak \& Frissel 2000; MacDonald et al. 2001); they also increase the concentration of pollutants and decrease species diversity (Weaver \& Garman 1994). An increase in sedimentation, alterations in river banks, and changes in the physical and chemical makeup of the stream can result in the reduction of habitat heterogeneity and the loss of sensitive species (Pérez-Reyes et al. 2016).

Though the correlation of the number of ovigerous females and juveniles with rainfall was not statistically significant according to the cross-correlation analysis, the number of juveniles did increase as rainfall decreased (from June to September 2006). Meanwhile, in rainier periods (from November 2006 to February 2007), the number of ovigerous females increased. Associations between reproductive peaks and months with high temperatures and rainfall were also observed in studies on $M$. olfersii (Mossolin \& Bueno 2002) and Atya scabra (Leach, 1816) (Galvao \& Bueno 2000), the latter of which is an atyid inhabiting the same type of ecosystem. In warmer and more humid months when reproductive activity is higher, the water volume in rivers increases and consequently facilitates the rapid movement of newly hatched larvae into the estuary (Mossolin \& Bueno 2002).

During the life cycle of $M$. olfersii, newly hatched individuals migrate to estuaries to complete their larval development and return in a post-larval state to the region where they hatched (Dugger \& Dobkin 1975). The decrease in the number of juveniles captured in periods with higher rainfall (October 2006 to May 2007) suggests that new recruits were unsuccessful in returning to the sampled site. These data reinforce the idea that the increase in river current volume may have been an obstacle to migration, and that individuals may have settled downstream in search of more favourable places. Extreme environmental conditions can increase or decrease shrimp densities (i.e. during storm flow or dry periods) (Pérez-Reyes et al. 2015).

The estimated size at which $50 \%$ of females reached sexual gonadal maturity $(6.70 \mathrm{~mm} \mathrm{CL}$, or $23.8 \mathrm{~mm} \mathrm{TL})$ was similar to that found among $M$. olfersii populations in Santa Catarina State (21.2 and 27.3 mm TL) (Ammar et al. 2001). In terms of functional maturity, the size of the smallest ovigerous female observed in this study $(7.90 \mathrm{~mm} \mathrm{CL}$, or $27.4 \mathrm{~mm} \mathrm{TL}$ ) was similar to the findings reported by Mossolin and Bueno (2002) in São Sebastião, São Paulo State (28.1 mm TL) and by Ammar et al. (2001) in Santa Catarina State $(27.3 \mathrm{~mm} \mathrm{TL})$. Although the size at first sexual maturity is expected to differ at different latitudes and between individuals at any given location (Campbell \& Fielder 1986), the $4^{\circ}$ difference in latitude between the present study region $\left(23^{\circ} \mathrm{S}\right)$ and the location sampled by Ammar et al. (2001) $\left(27^{\circ} \mathrm{S}\right)$ was not found to affect the size at which $M$. olfersii reached sexual maturity. Temperature was probably the more likely contributing factor to this similarity, since temperature values ranged from $18^{\circ} \mathrm{C}$ to $26^{\circ} \mathrm{C}$ (present study) and from $17^{\circ} \mathrm{C}$ to $29^{\circ} \mathrm{C}$ (Ammar et al. 2001). 
Macrobrachium olfersii was not captured during other sampling campaigns performed at the same study site from 2012 to 2015 . Several factors may have contributed to the absence of a species that had previously been abundant in this ecosystem. Considering the fact that $M$. olfersii was captured in a river located in an urban environment, the effects of human activity are not to be discarded. Changes in water chemistry (Humborg et al. 1997), the isolation of populations owing to habitat fragmentation (Winston et al. 1991), and the death of larvae and juveniles owing to water catchment for supplying riverine populations (Travnichek et al. 1993) are examples of direct ecological effects of human activity that can change the migration routes of species (Drinkwater \& Frank 1994). This abrupt change in the shrimp population could interfere with other organisms in the ecosystem. With the reduction or disappearance not only of the species studied but also of other shrimp found in this river during the same period, such as Atya scabra (Leach, 1815) and Potimirim brasiliana (Villalobos, 1960), changes may occur in the abundance of algae and insects in this environment (Pringle 1996).

Crustaceans are often used as bioindicators in aquatic systems, since they inhabit several ecosystems and are important components of the food chain (Chace \& Hobbs 1969; Shah \& Shah 2013). The results of this study, in which M. olfersii was abundant during the sampling period (from June 2006 to May 2007) with ovigerous females and juveniles, followed by its absence during other campaigns (from 2012 to 2015), provide strong indications that the ecosystem studied may have suffered some type of environmental stress that interfered in the migration of the species. The results reported by Pérez-Reyes et al. (2016) in the comparison of decapod communities of streams in an urban area of Puerto Rico suggest a negative effect of the physical, chemical and environmental impacts on the diversity and abundance of freshwater decapods in urban watersheds. In a study conducted in Costa Rica (Snyder \& Pringle 2013), $M$. olfersii populations in degraded rivers had an $87 \%$ decline in relative abundance when compared to populations inhabiting preserved rivers. As in Costa Rican populations, the M. olfersii population in the Taquaral River may have been affected by anthropogenic actions, which likely hampered the migration cycle and, as a consequence, the maintenance of the species in this highly urbanised ecosystem.

\section{Funding}

This work was supported by the São Paulo Research Foundation (FAPESP) under Young Investigators in Emerging Institutions Grant numbers 04/07309-8, 09/54672-4 and 2010/501888 (Tematic Biota, awarded to R.C.C.) and Scholarship number 07/50804-8 (awarded to M.F.C.), and the CNPq under Research Scholarship PQ 305919/2014-8 (to R.C.C.). We also thank the LABCAM coworkers for their help during field work. All exper- iments conducted during this study complied with current applicable state and federal laws in Brazil.

\section{References}

Ammar D, Muller YMR, Nazari EM. 2001. Biologia reprodutiva de Macrobrachium olfersii (Wiegman) (Crustacea, Decapoda, Palaemonidae) coletados na Ilha de Santa Catarina, Brasil. Revista Brasileira de Zoologia. 18:529-537.

Barros MP. 1995. Dados biológicos sobre Macrobrachium olfersii (Wiegmann, 1836) (Decapoda, Palaemonidae) da Praia da Vigia, Garopaba, Santa Catarina. Brasil Biociências. 3:239-252.

Bauer RT. 2004. Remarkable shrimps: adaptations and natural history of the carideans. Norman, OK: University of Oklahoma Press.

Bauer RT. 2011. Amphidromy and migrations of freshwater shrimps. II. Delivery of hatching larvae to the sea, return juvenile upstream migration, and human impacts. In: Asakura A, editor. New frontiers in crustacean biology. Proceedings of the TCS Summer Meeting; 2009 Sep 20-24; Tokyo. Leiden, The Netherlands: Brill; p. 157-168.

Bauer RT, Delahoussaye J. 2008. Life history migrations of the amphidromous river shrimp Macrobrachium ohione from a continental large river system. Journal of Crustacean Biology. 28:622-632.

Campbell GR, Fielder DR. 1986. Size at sexual maturity and occurrence of ovigerous females in three species of commercially exploited portunid crabs in SE Queensland. Proceedings of the Royal Society of Queensland. 97:79-87.

Campbell A, Robinson DG. 1983. Reproductive potential of three American lobster (Homarus americanus) stocks in the Canadian Maritimes. Canadian Journal of Fisheries and Aquatic Sciences. 40:1958-1967.

Chace FA Jr, Hobbs HH. 1969. The freshwater and terrestrial decapod crustaceans of the West Indies with special reference to Dominica. United States National Museum Bulletin. 292:1-258.

Cooney PB, Kwak TJ. 2013. Spacial extent and dynamics of dam impacts on tropical island freshwater fish assemblages. Bioscience. 63:176-190.

Drinkwater KF, Frank KT. 1994. Effects of river regulation and diversion on marine fish and invertebrates. Aquatic Conservation: Marine and Freshwater Ecosystems. 4:135-151.

Dugger DM, Dobkin S. 1975. A contribution to knowledge of the larval development of Macrobrachium olfersii (Wiegman, 1836) (Decapoda, Palaemonidae). Crustaceana. 29:1-30.

Galvão R, Bueno SLS. 2000. Population structure and reproductive biology of the Camacuto shrimp, Atya scabra (Leach, 1815) (Decapoda, Caridea, Atyidae), from São Sebastião. Brazil Crustacean Issue. 12:291-299.

Gherardi F, Micheli F. 1989. Relative growth and population structure of the freshwater crab, Potamon potamios palestinensis, in the Dead Sea area (Israel). Israel Journal of Zoology. 36:133-145.

Holmquist JG, Schmidt-Gengenbach JM, Buchanan Yoshioka B. 1998. High dams and marine-freshwater linkages: effects of native and introduced fauna in the Caribbean. Conservation Biology. 12:621-630.

Holthuis LB, Provenzano AJ. 1970. New distribution records for species of Macrobrachium with notes on the distribution of the genus in Florida (Decapoda, Palaemonidae). Crustaceana. 19:211-213. 
Humborg C, Ittekkot V, Cociasu A, Bodungen BV. 1997. Effect of Danube River dam on Black Sea biogeochemistry and ecosystem structure. Nature. 386:385-388.

Levinton JS. 1995. Marine Biology, function, biodiversity, ecology. New York, NY: Oxford University Press; P. 420.

MacDonald LH, Sampson RW, Anderson DM. 2001. Runoff and road erosion at the plot and road segment scales, St John, US Virgin Islands. Earth Surface Processes and Landforms. 26:251-272.

March JG, Benstead JP, Pringle CM, Scatena FN. 2003. Damming tropical island streams: problems, solutions, and alternatives. Bioscience. 53:1069-1078.

Melo GAS. 2003. Manual de identificação dos Crustacea Decapoda de água doce do Brasil. São Paulo: Edições Loyola; p. 429.

Moraes-Riodades PMC, Valenti WC. 2004. Morphotypes in male Amazon River Prawns, Macrobrachium amazonicum. Aquaculture. 236:297-307.

Mossolin EC, Bueno SLS. 2002. Reproductive Biology of Macrobrachium Olfersi (Decapoda, Palaemonidae) in São Sebastião, Brazil. Brazil Journal of Crustacean Biology. 22:367-376.

Mossolin EC, Bueno SLS. 2003. Relative growth of the second pereiopod in Macrobrachium olfersi (Wiegmann, 1836) (Decapoda, Palaemonidae). Crustaceana. 76:363-376.

Pérez-Reyes O, Crowl TA, Covich AP. 2015. Effects of food supplies and water temperature on growth rates of two species of freshwater tropical shrimps. Freshwater Biology. 60:1514-1524.

Pérez-Reyes O, Crowl TA, Covich AP. 2016. Comparison of decapod communities across an urban-forest land use gradient in Puerto Rican streams. Urban Ecosystems. 19:181-203.

Pringle C. 1996. Atyid shrimps (Decapoda: Atyidae) influence the spatial heterogeneity of algal communities over different scales in tropical montane streams, Puerto Rico. Freshwater Biology. 35:125-140.

Rossi N, Mantelatto FL. 2013. Molecular analysis of the freshwater prawn Macrobrachium olfersii (Decapoda, Palaemonidae) supports the existence of a single species throughout its distribution. Plos one. 8:e54698.

Sastry AN. 1983. Ecological aspects of reproduction. In:Vernberg FJ, Vernberg WB, editors. The biology of Crustacea, environmental adaptations. 8. New York, NY: Academic Press; p. 179-270.
Shah R, Shah D. 2013. Evaluation of benthic macroinvertebrate assemblage for disturbance zonation in urban rivers using multivariate analysis: Implications for river management. Journal of Earth System Science. 122:1125-1139.

Simons MJ, Jones MB. 1981. Population and reproductive biology of the mud crab, Macrophthalmus hirtipes (Jacquinot, 1853) (Ocypodidae), from marine and estuarine habitats. Journal of Natural History. 15:981-994.

Snyder MN, Pringle CM. 2013. Landscape-scale disturbance and protected areas: long-term dynamics of populations of the shrimp, Macrobrachium olfersii in lowland Neotropical streams, Costa Rican. Journal of Tropical Ecology. 29:8185.

Sokal RR, Rohlf FJ. 1981. Biometry. San Francisco: Freeman; P. 22.

Sokal RR, Rohlf FJ. 1995. Biometry. 3a ed. New York, NY: Freeman W.H. and Co; P. 887.

Travnichek VH, Zale AV, Fisher WL. 1993. Entrainment of Ichthyoplankton by a Warmwater Hydroelectric Facility. Transactions of the American Fisheries Society. 122:709-716.

Trombulak SC, Frissell CA. 2000. Review of ecological effects of roads on terrestrial and aquatic communities. Conservation Biology. 14:18-30.

Valenti WC.1985. Cultivo de Camarões de Água Doce. São Paulo: Nobel; P. 82.

Valenti WC. 1998. Carcinicultura de água doce: Tecnologia para produção de camarões. Brasilia: IBAMA; P. 383.

Vazzoler AEAM. 1996. Biologia Da Reprodução De Peixes Teleósteos: Teorias E Prática. $1^{\text {a }}$ ed. Eduem, Maringá; P. 169.

Vieira S. 2011. Introdução à Bioestatística. 4ª ed. Elsevier, Campus, Rio de janeiro; P. 345.

Weaver LA, Garman GC. 1994. Urbanization of a watershed and historical changes in a stream fish assemblage. Transactions of the American Fisheries Society. 123:162-172.

Wenner AM. 1972. Sex ratio as a function of size in marine crustacea. The American Naturalist. 106:321-350.

Winston MR, Taylor CM, Pigg J. 1991. Upstream extirpation of four minnow species due to damming of a prairie stream. Transactions of the American Fisheries Society. 120:98105.

Zar JH. 1996. Biostatistical Analysis. 3a ed. New Jersey: Prentice Hall. 